Fekete Judit

\title{
A jóléti állam mint a modern civilizáció vívmánya: merre tovább?
}

\begin{abstract}
„A közgazdásznak sokkal inkább hasznositani kellene mindazt a tudást, amelyet napjaink szociológiája, politikatudománya, szociálpszichológiája és történelemtudománya felhalmozott. Minderre szükségünk van ahhoz, hogy helyes normatív következtetéseket vonhassunk le." (Kornai)
\end{abstract}

A szerző a jóléti állam indíttatására, eddigi gyakorlatára pillant vissza, és vizsgálja, hogy milyen tanulságokkal szolgálnak a tapasztatok a jelenlegi problémák hatékony kezelése szempontjából, mire figyelmeztet az egyes kormányzatok és a társadalmi jólét egymáshoz füződő viszonya ma, amikor gazdaságilag és társadalmilag egyaránt sürgető kényszer a költségvetési, adóztatási szociális, egészségügyi, oktatási stb. rendszerek súlyosbodó feszültségeinek csökkentése. Konklúziója, hogy alapvető szemléletváltásra, új állami szerepvállalásra van szükség, továbbá a gyökeresen megváltozott gazdasági körülményeknek, valamint a reális társadalmi igényeknek egyaránt megfelelő új intézményekre, módszerekre és eszközökre.*

„Hogyan kell berendezni az államot ahhoz, hogy biztosítani tudja polgárainak az ember számára elérhető legnemesebb, legjobb élet külső feltételeit, s ösztönözzön, rá is vezessen erre a legjobb, legnemesebb életre?” - kérdezi már Arisztotelész az időszámítás előtti negyedik században. „Jóléti államnak azokat az államokat szokták nevezni, amelyek elkötelezettek polgáraik anyagi és szellemi «jól-léte» (jó egészégi állapota, korszerü müveltsége és modern gazdaságban való foglalkoztathatósága, a munkára való alkalmassága, továbbá megfelelö lakhatása és táplálkozása) iránt, és ennek érdekében aktívan beavatkoznak a gazdasági folyamatokba." - definiálja Szabó Katalin (Szabó 2000:209) Lampman alapján.

Voltaképpen tehát Arisztotelész ősi kérdésére keresi a választ a jóléti állam is több mint kétezer évvel később. Ahogy Arisztotelész filozófiáját a kettőség jellemezte: ingadozás az idealista és a materialista elképzelések között, úgy a jóléti állam teóriáját is áthatja az ambivalencia: a társadalmi igények és a gazdasági lehetőségek, a vágyak és realitások egymásnak feszülő szempontjai. Az egyén is felemásan viszonyul ehhez a kérdéshez: „Az embereket irritálja a magánéletbe beavatkozó, az egyént zaklató állam - de sokan most is igényt tartanának a gondoskodó paternalista államra." (Kornai 1993a:139)

*A cikk a Debreceni Egyetem Közgazdaságtudományi Kar Doktori Iskolájában 2004. január 15-én tartott előadásom anyagából készült. Köszönettel tartozom Csaba Lászlónak gondolatébresztő kérdéseiért, értékes észrevételeiért és Láng Eszternek igényes szerkesztői munkájáért.

Fekete Judit a Magyar Tudományos Akadémia Politikai Tudományok Intézetének tudományos munkatársa.

E-mail:jfekete@mtapti.hu 
A jóléti állam is sokoldalú, sokszínü, összetett jelenség. „Nem választható el a közgazdaságtantól - mondja Nicholas Barr -, része annak, és hatékonysággal kapcsolatos tételei, megállapitásai levezethetők a közgazdasági tételekböl."” Átfogó jellemzéséhez ugyanakkor a filozófia és több szaktudomány eszköztára szükséges. A jóléti állam problémája egyetemes társadalmi probléma. A jóléti állam teóriája ideológiai elfogultságokkal és politikai hitekkel terhes. A jóléti állam problémakörében jelen vannak filozófiai, szaktudományos, ideológiai, politikai kérdések egyaránt.

A jóléti állam társadalom-és erkölcsfilozófiai kérdéseket érint: egyén és társadalom, egyéni szabadság, társadalmi felelősség, szuverenitás, szolidaritás, méltányosság, igazságosság, egyenlőség, az állam szerepe a társadalomban stb.

Az egyes szaktudományok vonatkozásában gyakori átfedések mellett politológiai kérdéseket ( hatalom, legitimáció, bürokrácia, társadalmi elégedettség stb.), jogi (tulajdon, szerződések, törvények, alkotmányosság, jogi intézmények, szervezetek, szabályozás stb.), szociológiai (társadalmi egyenlőtlenség, esélykülönbség, szegénység, gazdagság, öregedés, szolidaritás, életminőség, társadalmi bizalom, deviáns magatartások, rétegmagatartások, alkalmazkodás, tanulás stb.), gazdaságtörténeti és történelemtudományi kérdéseket érint (válságokat, háborúkat, recessziókat, kiútkereséseket). Több történelmi helyzetben, különböző társadalmi berendezkedésekben, eltérő gazdasági adottságok mellett, más helyszíneken és korszakokban, különböző típusai léteztek (Szabó Katalin felosztása szerint: liberális, szociáldemokrata, koraszülött kelet-európai, vagy Esping-Andersen tipológiája szerint: liberális-reziduális, konzervatív, szociáldemokrata). Valamennyi fajtája meghatározó befolyást gyakorolt az adott és a későbbi időszak gazdaságára és társadalmára. Végül, de nem utolsó sorban általános és alapvető közgazdasági kérdéseket tartalmaz a jóléti állam kérdésköre: hatékonyság, gazdasági növekedés, válságkezelés, beruházás, fogyasztás, elosztás, adóztatás, eladósodás, állami költségvetés, gazdasági egyensúly, szociálpolitika, piac, urbanizáció, modernizáció, ipari társadalom, információs társadalom, globalizáció stb. és nem sorjázom tovább, idéztem már Barrt. És milyen igaza volt Hayeknek is: „A közgazdaságtan ... komplex jelenségekkel foglalkozó tudományág.” (Hayek 1995:313)

Az ideologikus indíttatású értékelések végigkísérték a jóléti állam történetét. Az ötvenes években a konzervatívok bírálták inflációs hatásai miatt. Tíz évvel később a baloldal támadta, amiért nem teremtett kielégítő egyenlőséget. A hetvenes években újra a jobboldal lendült támadásba az „,adóztató-költekező állam” és a „kormányzati túltengés” diagnózisa következtében. ${ }^{2} \mathrm{~A}$ jóléti állam válságát is különböző értelmezésekkel és sajátosságokkal illetik a nagy ideológiai áramlatok. A liberalizmus a hatalom, a legitimáció és a bürokrácia kérdései felöl közelíti meg a válságot. A konzervatív irányzat a társadalmi integráció oldaláról ragadja meg a válság sajátosságait. A marxista álláspont a kapitalista fejlődés általa vélt fejlődési logikájából következtet a jóléti állam válságára. ${ }^{3}$ Végül a politikai vonatkozásokhoz még azt füzzük a jóléti államok esetében, hogy az állami beavatkozás és az újraelosztás mértékével, irányával és természetével kapcsolatos viták és alternatívák szorosan kapcsolódnak a politikai aréna, a kormányzati hatalom szereplőihez. A lakosság jólétének feladatára általában nagy súlyt fektetnek a különböző pártok és kormányok nyilvánosság-

'Barr, Nicholas A. (1992): Economic Theory and Welfare State: A Survey and Interpretation. Journal of Economic Literature, vol. 30. Issue 2: 741-803. (Idézi Szabó 2000:209)

${ }^{2}$ Offe (1984) mindkét oldal bírálatait összefoglalja.

${ }^{3}$ Bövebben lásd Csaba I.- Tóth szerk. 1999. 
ra hozott politikai programjai. Egyetértek azonban Kornaival (1993a:24), hogy ne legyenek illúzióink: „Hibás feltételezés arra számítani - mondja -, hogy bármely kormány ... a társadalmi jóléti függvényt maximalizálja ... Ha egyáltalán szóba jöhet bármilyen végső cél, akkor ez a politikai uralmon lévők hatalmának megtartása, nem pedig a társadalom jóléte." Buchanan (1992) és követői is abból indulnak ki, hogy a politikusok nem a közjó, hanem saját hatalmuk maximalizálásában érdekeltek.

Nézzük meg közelebbről, mi volt tehát a jóléti állam bevezetésének tényleges indíttatása a nyugati országokban, és mi volt nálunk. Tekintsünk vissza céljára, törekvéseire, majd konkrét megvalósulására, jellemzőire, ellentmondásaira, eredményeire és kudarcaira itt és ott. És tegyük mindezt azért, hogy megvizsgálhassuk a jóléti állam megkérdőjelezésének okait. Hogy fogódzókat találhassunk a jóléti állam újragondolásához; majd megoldásokat a jóléti rendszerek reformjához az átmenet időszakában, az új, globalizált világban, a demográfiai folyamatok drámai változása mellett is.

\section{A jóléti állam indíttatása a kapitalista Nyugaton}

Kezdjük egy kis időutazással! Ha visszafelé haladunk az időben: Napjainkban kérdőjeleződött meg a jóléti állam paradigmája, fenntarthatósága és jövője. A kilencvenes években általános válságáról beszéltek. A nyolcvanas években a jóléti állam ellentmondásai kerültek a figyelem középpontjába és a „kormányzati túltengést” diagnosztizálták. ${ }^{4}$ A hetvenes években a jóléti állam sérülékenységével, az első krízisjelekkel szembesülhettünk, amikor is megtorpant az addigi töretlen lendület a két olajválság nyomán. A jóléti állam itt fordulóponthoz érkezett. A hetvenes években emelkedik fel a neoliberális közgazdasági iskola is, amelynek két jeles képviselője, Hayek és Friedman a szabadság elvesztésének veszélyét látja a jóléti államban. ${ }^{5}$ Folytatva az utazást visszafelé az időben, a jóléti állam beavatkozásaiban a hatvanas években még a jótékony gondoskodást látták elsősorban a (gazdasági stabilitással és viszonylag teljes foglalkoztatással együttjáró) „szociális piacgazdaságot”, amely korrigálja és kiigazítja a piacot. ${ }^{6}$ Az ötvenes években az egymást követő jóléti programok, az állami szociális kiadások expanziója kapott kitüntető figyelmet. E tradicionális jóléti állam kibontakozásának a korszaka a nagy válságot és a második világháborút követö, harmincas, negyvenes évek második felére tehetö. Az intézmény gyökerei azonban $a$ tiyenkilencedik századig nyúlnak vissza.

Ha visszatekintünk az indíttatásra, választ kaphatunk arra, hogy a történelmi tapasztalat igazolja-e már a kezdeteknél Kornai, Buchanan és mások vélekedését a kormányok, politikusok és a társadalmi jólét viszonyát illetően. Ne rövid kitérőként tekintsünk erre! Inkább olyan jelenség jelzéseként, amely már a kezdetekkor megfigyelhető volt és hatást gyakorolt a későbbi évtizedek történéseire is. Ez fontos kérdés továbbá azért is, mert jelenleg is a politikai aréna küzdőterében döntenek a jóléti rendszerek reformjának kérdéseiről, állami szerepvállalásokról, költségvetési, szociális kiadásokról, adókról, egészségügyi reformról és privatizációról stb. Ezzel kapcsolatban Kornai már 1993-ban figyelmeztetett

\footnotetext{
${ }^{4}$ A „nem piaci kudarcok elméletéről” először ifj. Charles Wolf publikált 1979-ben. Innen nő majd ki a mára jól ismert „kormányzati kudarcok elmélete” (vesd össze Le Grand 1999).

${ }^{5}$ Berend T. kesernyésen jegyzi meg: „Ezeket a nézeteket mind Hayek, mind Friedman esetében Nobel-díj emelte a magasba az 1970-es években". (Berend T. 2003:1278)

${ }^{6}$ Lásd Arrow 1963, Samuelson 1969, Akerlof 1970.
} 
arra, hogy „Szívósan és erélyesen kell szorgalmazni a korábbi hiperaktív állam szerepének visszaszoritását és ezzel együtt az állami kiadások csökkentését, szembeszállva az állandóan újraéledö centralizációs, bürokratikus tendenciákkal." (Kornai 1993a:142-143) Továbbá, ha visszapillantunk a múltra, láthatjuk, hogy a történelmi tapasztalat visszaigazolja-e azt - a szakmában szinte evidenciának számító - állítást, hogy a jóléti állam csak a gazdag országok luxusa lehet, és ott is csak a nagy prosperitás időszakában. Kornai megfogalmazásával élve: „Általános megfigyelés, hogy szoros pozitív összefüggés van egy ország gazdasági fejlettsége és jóléti szolgáltatásainak méretei között." (Kornai 1993a:138) Legyünk precízek: Kornai ehhez hozzáteszi, hogy „Nem a fejlettség az egyedüli, de kétségkívül az egyik alapvetö meghatározó tényezö." (uo).

„Egyszer volt, hol nem volt”, a tizenkilencedik század végén, a német „vaskancellár”, Bismarck felismerte, hogy a szociáldemokrácia betiltásának fegyvere fordítva sült el, és fokozatosan a legnagyobb párttá tette azt. „Ekkor úgy akarta kifogni a szelet ellenzéke vitorláiból, hogy átvette annak szociális programját, és nekilátott megvalósitásának: így került sor 1883-ban a világ elsö kötelezö nemzeti betegbiztositási programjának bevezetésére. A következö években ezt követte a kötelezö ipari balesetbiztositás meghonosítása, majd 1889ben a nyugdij és rokkantsági nyugdí intézményeinek bevezetése. Mindez nem állampolgári jogon járt, csak a szocialisták tömegbázisát célozta meg: az ipari munkásokra vonatkozott." (Berend T. 2003:1273-1274) Milyen az élet?! Az az ország - Németország - ahonnan a jóléti állam elindult, később nem tartozik majd a jóléti államok kategóriájába. A jóléti OECD-államok szokásos csoportjába Belgium, Dánia, Finnország, Franciaország, Hollandia, Norvégia, Svédország tartozik.

Ugyancsak a tizenkilencedik század nyolcvanas éveiben, a harmadik köztársaság legitimációjának érdekében vezették be Franciaországban is az ingyenes, kötelező és központosított elemi oktatást. Azt a célt szolgálta, hogy elterjessze és megerősítse a köztársasági eszméket és a szociális, világi gondolkodást az egyházi befolyással szemben (Nagy 1998). Tehát amíg ugyanabban az időben az új német birodalom legitimációja érdekében, a szocialista befolyás terjedésével szemben vezeti be Bismarck a társadalombiztosítást, továbbá - a szakszervezetek elnyomása mellett - a munkaszerződések és munkásbiztosítások elfogadására kényszeríti a munkaadókat, Franciaországban csak az oktatásra terjed ki az állami gondoskodás, mert itt ez az, ami a köztársaság legitimációját szolgálja az egyházi befolyással szemben.

Mintegy fél évszázaddal később, az a lépés, amikor az Egyesült Államokban - ahol mindaddig ismeretlenek voltak a jóléti intézmények - Roosevelt bejelentette a social security intézményének bevezetését, szintén legitimációs kényszerből történt. A Nagy Válságot követően a kormányzatnak föl kellett lépnie az egyre fenyegetőbb jobb- és baloldali populizmusok szélsőségeivel szemben (Berend T. 2003). Ekkor - a populista fenyegetettség közepette, a nyomor és munkanélküliség mélységes bugyrában - jelentette ki az elnök, hogy „a demokráciának be kell bizonyítania, hogy kormányai felelösséget vállalnak népeik szociális biztonságáért"? A A szándék szerint ezt jelenítette meg a New Deal vagy az 1936-ban bevezetett első társadalombiztosítás is. A Nagy Válság időszakában alakult ki az első átfogó jóléti állam is Svédországban, 1932-ben, a kormányhatalomhoz jutott szociáldemokrácia vezetésével. 
A „jóléti állam” elnevezés Temple yorki érsek nevéhez füződik, aki a háború idején megjelent írásaiban szembeállította a náci diktatúra háborúra és erőszakra épülő elkötelezettségét a demokráciák jólét iránti elkötelezettségével, azaz a hatalmi államot a jóléti állam megvalósításának lehetőségével. ${ }^{8}$

A háború nyomorúsága közepette a jobblét iránti tömeges vágyakozásnak és társadalmi várakozásnak kellett megfelelniük a majdani győztes hatalmaknak. Ezzel is igazolva fölényüket. A társadalmi szolidaritás háborús tapasztalata is erre sarkallt. Lényegében ezt az elvárást fogalmazta meg Roosevelt híres 1941. január 6-i beszédében, amikor az „ínségtől való szabadságot” is felsorolta a „négy szabadság” között, amelynek megvédelmezésére felszólította a Kongresszust.

Ezt a társadalmi igénynek való megfelelési kényszert ismerte föl a konzervatív Churchill-kabinet. Egyik tagja, a liberális politikus közgazda Beveridge 1942-ben kidolgozta az első átfogó jóléti törvényhozási tervet, amelyben egy széleskörű társadalompolitikai program részeként fogalmazta meg a társadalombiztosítás reformját. Leszögezte, hogy $a$ katonai „gyözelem célja, ... hogy a háború után jobb világban élhessünk, mint korábban. Meg kell szabadulni a szükségtöl”. " „Minden állampolgár ingyenes egészségi ellátáshoz kell, hogy jusson. A gyermekek után támogatást kell nyújtani a családoknak, s az idösebb generációknak biztonságot teremtö nyugdijat kell folyósítani. Így került sor Angliában 1945 és 1948 között, amikor még jegyre osztották az élelmiszert és nélkülözött a lakosság, az átfogó jóléti törvényalkotásra." (Berend T. 2000: 1274)

„Franciaországban a felszabadulást követöen ... a németekkel szembeni ellenállás különbözö irányzataiból, koalíciós kormány alakult, valamennyi politikai párt részvételével, feléledtek és megerősödtek a szakszervezetek, meggyengültek a részben kollaborációval kompromittálódott korábbi munkaadói érdekszervezetek, az Ellenállás Nemzeti Tanácsának programja a modernizálás és a széles körü állami gondoskodás igéretével lépett fel. 1945-ben ilyen körülmények között helyezték új alapokra, szélesitették ki és alakitották át gyökeresen a társadalombiztositás rendszerét." (Nagy 1998:458)

Jóléti intézményeket vezettek be más Nyugat-európai országokban is, Dániában, Németországban, Svájcban Belgiumban. A második világháború utáni újjáépítés a jóléti programok és kiadások expanziójával párosult, ${ }^{10}$ és ez folytatódott a két olajválság nyomán kibontakozott recesszió jelentkezéséig. E folyamat mentén számolni kell a hidegháború hatásával is. A katonai gazdasági verseny mellett jóléti verseny is kibontakozott a két párhuzamosan létező és egymással szemben álló világrend között. A Nyugat „emberarcú kapitalizmusa” a szocializmus „egyenlősíto"” elveivel vette föl a versenyt. (Berend T. 2003)

${ }^{8}$ Temple, W. (1941): Citizen and Churchmann. London, Eyre and Spotiswoode; (1942): Chirstianity and the Social Order. London, Penguin; Pierson, C. (1994):Beyond the Welfare State? Cambridge, Polity Press. (E munkákra hivatkozik Csaba I. - Tóth 1999:8 és hangsúlyozza ezt a szembenállást. Berend T. is kiemeli és fontosnak tartja ezt az összevetést. Berend T. 2003:1274)

${ }^{9}$ Idézi Berend T. 2003:1274

10 Nyugat-Európa egészét nézve négyszer annyit költött az állam szociális kiadásokra 1957-ben, mint a háború elött. A nemzeti jövedelem 40-50\%-át fordították jóléti kiadásokra. (Berend T. 2003: 1275.) 


\section{A jóléti állam indíttatása a reformszocializmusban}

Magyarországon 1968-1989 között reformszocializmus ${ }^{11}$ müködött. Legelöször a volt Jugoszláviában létezett 1950-től. Lengyelországban 1981-töl 1989-ig, a volt Szovjetunióban 1985-tól 1991-ig volt reformszocialista rendszer. Kínában 1978-tól, Vietnamban 1987-től van. A korszakot a jugoszláv Tito, a magyar Kádár, a kínai Teng Hsziaó-ping, a lengyel Rakowski és a szovjet Gorbacsov vezető politikusok neve fémjelzi.

A szocializmusról folytatott elméleti vitákban már korábban megjelent az a gondolat, hogy a társadalmi jólét növelése még a kommunista rendszerben sem biztosítható másképpen, mint a verseny és a piac erőinek aktivizálásával. ${ }^{12} \mathrm{~A}$ gyakorlati kísérletezések során, a bevezetett reformok nyomán igyekeztek összeházasítani a központi tervezést a piaccal. Ez tűz és víz! „Összeegyeztethetetlen” - mondja majd Kornai. Nem így gondolták az akkori döntéshozók. „Az eredeti modell is emberi ötletek eredményeképpen, tervszerűen jött létre!” - gondolhatták. „És amit ember teremtett, azt tetszése szerint meg is változtathatja,” - vélték. Hozzáállásukban nem számoltak azzal a nézettel, hogy születhet olyan eredmény is, amely az „emberi cselekvés hatására, de nem általa szándékoltan” jön lére. Ki gondolna Hérodotoszra - hogy Hayekről ne is beszéljünk -, amikor a világot akarja megváltani?

Az így létrehozott produktumról Kornai (1993a:40) azt mondja: „A piaci szocializmus egyik veleszületett gyengesége az, hogy mesterséges agyszülemény; Hayek kifejezésével: konstruktivista képzödmény." A piac aktivizálásában és a tervgazdaság lazításában legtovább az 1968-ban bevezetett magyar „új gazdasági mechanizmus” jutott. Azonban még ennek eredménye sem lett olyan modell, amely „,tervszerüre IS, piacira IS” sikeredett volna, hanem a reform egy „SEM terv, SEM piac” képződményt eredményező konstrukciót szült. ${ }^{13}$ Vagy inkább csak bábáskodott felette? „Megesik”. Nem ez az első ilyen eset. A történelem természetesen többször is tanúja volt különbségeknek a szándék és az eredmény között. „A népek olyan intézményekkel találkoznak, melyeket emberi cselekvés hozott létre, de nem emberi szándék megtestesülései." - mondja Adam Ferguson 1767-ben, idézi Hayek 1967-ben. (Hayek 1995: 292) „A francia forradalom sorsa kevéssé hasonlitott azokra az ideákra, amelyeket az enciklopédisták, közöttü̈k Rousseau, müveikben kifejtettek, és az 1930-as évek Szovjetunója is egészen más országnak bizonyult, mint ami Marxnak vagy az 1917-es forradalom résztvevöinek elképzelésében élt" - jegyzi meg Kornai is 1993-ban (1993a:47).

A reformszocializmusban az eltérések az eredeti céloktól olykor olyan nagyok voltak számos területen, hogy a tényleges eredmény a kiinduló elgondolásoknak a közelébe sem került. Így volt ez a jóléti rendszer esetében is. Ennek bemutatásakor a magyar reformszocializmus példájára támaszkodom.

${ }^{11}$ A reformszocializmus fogalmával azt a modellt illetjük, amely eltér a klasszikus szocializmus modelljétől annyiban, hogy némi liberalizációt visz a politikai szférába, bizonyos mértékben decentralizálja a gazdaság állami szektorának irányitását, és nagyobb játékteret hagy a magánszektornak. Ezek a változtatások indokolják a reform elnevezést. Ugyanakkor nem változtat az eredetin az alapvető modelljellemzők, a meghatározó jegyek tekintetében: marad az egypártrendszer, a kommunista párt továbbra is osztatlan hatalommal rendelkezik, az állami szektor domináns szerepet játszik és a gazdasági folyamatok fö koordinátora változatlanul a központosított bürokrácia (még ha az irányítás módszerein némileg változtattak is). Az alapjellemzők megőrzésével a modell a rendszeren belül marad, erre utal a szocialista elnevezés. (Kornai 1993/a: 45, bővebben Kornai 1993/b)

12 Ez a felvetés 1908-ig nyúlik vissza és Baronétól eredeztethető. Ezt a gondolatot viszi tovább Lieberman, Brus, később Liska. Elméleteiket a „szocializmus versenypiaci modelljének” tekintjük. (Hámori 2000:270)

${ }^{13} A$ "se terv, se piac" elnevezéssel elöször Bauer Tamás jellemezte a rendszert. (Bauer 1982) 
A reform szellemében az állam - induláskor - szeretne megszabadulni jóléti állam funkciójától. (Azaddigi hivatalos ideológia szerint ugyanis a paternalista államnak kellett gondoskodnia állampolgárai jólétéről.) A jogosultság és a finanszírozhatóság egymásnak feszülő szempontjait látva és hatékonysági megfontolásokra hivatkozva a reform hivatalos ideológiája feladja ezt a kötelezettséget. Korábban vállalt, de teljesíthetetlennek bizonyult feladataitól szabadulva nemcsak nem tudja, már nem is akarja azt a látszatot kelteni, mintha ,jólétiállamként" müködne. Szeretné mind nagyobb mértékben áthárítani a fogyasztás költségeit az egyénre, a családra, a háztartásra. Sorozatos elhatározások születnek a súlyos veszteségekkel fenntartott ingyenes vagy kvázi ingyenes állami lakásszektor, közlekedés és más közszolgáltatások számára nyújtott költségvetési támogatások határozott csökkentésére, az élelmiszerek és más tömegfogyasztási cikkek szubvencióinak leépítésére. A reform kapcsán bevallja azállam, hogy képtelen eleget tenni korábbi vállalásainak, és kezdi rátukmálni a családra a gyerek, a betegek és az öregek ellátásának feladatát, és ráhárítani annak költségeit (Kornai 1993b:479, 560).

A fenti célkitűzések szinte felismerhetetlenek a későbbi gyakorlati tapasztalatok fényében. A reformszocializmus korszaka olyan széleskörű szociálpolitikát, olyan átfogó szociális hálót, olyan méretü egészségügyi ellátást és oktatási rendszert müködtetett, amely messze meghaladta a gazdaság potenciálját és lehetőségeit, sőt nemzetközi összehasonlításokban is kiemelkedően magas jóléti kiadásokat produkált. Ahelyett ugyanis, hogy megvált volna túlzott jóléti terheitől - ahogy azt az új gazdasági mechanizmus indításakor tervezte - tovább tetézte azokat újabb, 1968 után bevezetett kedvezményekkel, sőt évenként-kétévenként fontos lépésekben beindította a jóléti rendszerek kiépítését is. (A klasszikus szocializmus korszakában a jóléti rendszerek csak nagyon kezdetlegesen müködtek.) Ez folyamatosan, öles lépésekkel haladt elöre. Az 1980-as évekre ennek mentén kialakult helyzetkép a következő: munkahelybiztonsággal együtt járó teljes foglalkoztatás, a munkahely révén szerzett és törvényekkel szentesített jogosultságok kiterjedt köre, a tanulással vagy az öregkorral összefüggő jogosultságok széles skálája, különböző pénzbeli járandóságok, a gyermekneveléssel, a betegséggel kapcsolatostársadalombiztosításijárandóságok. Ezt tetézte az árak és szolgáltatások széles körét érintő ártámogatási rendszer, valamint a lakásépítésnek a központi újraelosztás csatornáin keresztül történő támogatása (Kornai 1996:176).

Hasonló képet mutatnak a számok is. Magyarország GDP-hez arányított szociális kiadásai (1980-ban 21,8\%, 1986-ban 24,4\%) nemcsak a többi szocialista országét múlta felül, hanem azokét a nyugatiakét is, amelyekhez a gazdasági fejlettség tekintetében közel állt. (Pl. Görögországét, ahol ez 12,6\%, majd 19,5\% volt, vagy Spanyolországét, ahol ugyanez $15,6 \%$, majd $17 \%$ volt. Spanyolországot nézve nálunk még a növekedés üteme is nagyobb volt: 1980-ról '86-ra náluk 1,4\%, nálunk 2,6\%. Közbevetjük, hogy Svédországnál ugyanekkor ugyanez 1,2\%-os csökkenést mutatott.) És felülmúlta az Egyesült Államokét (ott a kormányzat szociális kiadásai a GDP-hez arányítva az évtized elején és közepén is $18 \%$ volt). A magyar reformszocializmus szociális kiadásainak szintje elmaradt ugyan a fejlett jólétiállamokétól, de megközelítette a fejlett európai országokét (pl. Nyugat-Németországét vagy Olaszországét). Folyamatosan nőtt a társadalombiztosításra fordított kormányzati kiadás is (az 1980-as évek végére már meghaladta a GDP 18\%-át, ami 1989-ben már több, mint 300 milliárd forintot jelentett.) (Kornai 1993a:135-138). 
Ha egy mondattal kellene válaszolnunk: Mindez legitimációs célból, a hatalmon lévők politikai érdekében történt. Hogy a produktum mögött a rendszer legitimációja és a hatalom megtartásának az érdeke áll, két stádiumban is nyomon követhetö.

Az első fokozatot a klasszikus szocializmusban indították be, amikor a rendszer felsőbbrendűségét kellett igazolniuk a hatalmon lévőknek. A második lökést 1956 traumája adta, az uralkodó politikai csoport katartikus élménye, hogy - Kornai szavaival élve - „egy felháborodott nép elsodorhatja és elüldözheti öket. Ezért jóban kell lenni a néppel" (Kornai 1996:176).

Nézzük meg közelebbről az okokat, indítékokat, mozgató rugókat! Miért szaladtak előre, mi üzte, hajtotta jóléti politikájukban a hatalmon lévőket?

ad. 1. Az első szakaszban a startpisztoly ravaszát az húzza meg, hogy a hivatalos ideológia (és a hatalmon lévő politikai vezetés meggyőződése) szerint (is), a szocializmus a kapitalizmusnál gazdaságilag és erkölcsileg egyaránt felsőbbrendű rendszer. A gazdasági fölény magából a rendszer alaptulajdonságaiból következik, amelyek garantálják, hogy ez rövidesen megmutatkozik. (Közbevetjük, hogy ez a „merész” feltételezés valószínűleg befolyásolhatta a „merész” vállalásokat is: lehet ígérni füt-fát, tejjel-mézzel folyó Kánaánt, hiszen a gazdaság gyors felfutása rövidesen fedezetet nyújt majd ezen ígéretek beváltásához.) Erkölcsi fölényét pedig az mutatja, hogy tisztább és nemesebb rendszer, amely biztosítja a társadalmi igazságot és egyenlőséget. Mindebből egyenes út vezetett a „MEGMUTATJUK!" felé.

A hatalomra került párt olyan alapvető ígéreteket tesz a lakosságnak, hogy „a szocializmus hamar utoléri, sőt túlhaladja” a kapitalizmus gazdasági fejlettségi szintjét, és hogy ,az egyénről majd az állam gondoskodik". (Korábban a forradalmi mozgalmak programjai is az egyenlőtlenség megszüntetését, a javak igazságtalan elosztásának felszámolását ígérték hatalomra kerülésük esetére. Az európai szocialista pártok eszmei hagyományaiban, a munkásmozgalom ideológiájában is benne gyökerezett a gondoskodó állam.) Nyomor van és tart még a zűrzavar, amikor a kormányzat már hasonló szerepre vállalkozik, illetve olyan kötelezettségvállalásokat tesz, mint amelyek ellátásával még a gazdasági fejlettség magas szintjén álló jóléti államok is csak próbálkoznak. A kijelölt állami gondoskodás összetevői a következők: a munkahely biztosítása (a munkaképes egyénnek alkotmányos joga van a munkára), állami feladat a lakosság alapvető szükségleteinek kielégítése (az élelem, a hajlék, az egészségügyi ellátás, az oktatás, az üdülés, a kulturális javak és szolgáltatások biztosítása). Mindezek következtében a klasszikus szocialista rendszerben az állam alkotmányos kötelezettséget vállalt arra, hogy jó néhány alapszükségletet ingyenesen vagy csekély térítés ellenében fog kielégíteni. Bevezette az ingyenes egészségügyi szolgáltatást, közoktatást. Szinte az egész lakosságot átfogó, központosított állami nyugdíjrendszert müködtetett. Ártámogatást adott az élelmiszerekhez. Szinte nevetséges szintű állami lakbéreket szabott meg. Társadalmi biztonsági hálót tartott fenn.

Mindez a gondoskodás azonban az állam gyámkodását és ellenőrzését is jelentette a lakosság felett: minden elesettet felfog, de mindenkit - saját lábon megállót is - fogva tart az egész társadalmat átszövő állami háló. Ezzel a gondoskodással együtt jár az egyén szabad választásának korlátozása. (Pl.: munkakényszer; újfajta „röghöz kötés”: munkahelyhez, lakhelyhez, lakáshoz; kötelezően kijelölt iskola, kórház, orvos.) Hayek evidens következménynek tartja, hogy az egyenlősitő ideológia ára az egyéni szabadság föladása. A hatalmon lévők mentalitása szerint: a párt/állam a szülő, a társadalom minden más tagja pedig a gyerek, aki gyámságra szorul, aki helyett a felnőtt gondviselőnek kell döntenie. 
Az állam üzenete: „az állampolgár fogadjon szót, s akkor nem lesz semmi gondja: a párt, az állam ellátja mindennel." (Kornai 1993b:89)

Kant már 1793-ban kijelentette, hogy a paternalista állam passzív, kiszolgáltatott alattvalókat nevel. Napjainkban Csaba László úgy fogalmaz, hogy 'az állami gyámkodás és ellenőrzés légköre államfüggö, önállótlan, segítségre szoruló, bérből élők társadalmát hozta létre, nem pedig az öntudatos és saját kezdeményezésére büszke állampolgárok nemzedékeit nevelte ki'. (Csaba L. 2000a:263-264) A határtalan ígérgetések mellett ez is közrejátszott abban, hogy irracionálissá torzultak a társadalmi várakozások és közösségi preferenciák. És ezek azok a társadalmi emóciók, amelyek aztán később, a reformszocializmusban majd elutasítják számos jóléti kedvezmény visszavonását, de még mérséklését is.

A jóléti kérdések terén a reformszocializmus tehát lényeges örökséget kapott a klaszszikus szocializmustól: egyrészt alkotmányosan rögzített, törvényekben garantált, szinte az egész társadalomra kiterjedő jóléti kötelezettségek és szociális juttatások nagyon széles körét, másrészt irreálisan magas, irracionálisan nagy társadalmi elvárásokat az állammal szemben. Innen indult a következő stádium.

ad. 2. 1956 megrázkódtatása arra sarkallta a politikai vezetést, hogy inkább előre meneküljön, mint hátra. Ez a túlélési stratégia áll annak a hátterében, hogy a reformszocializmus gyakorlatában nem viszik keresztül a reformszocializmus szellemében eredetileg eltervezett intézkedéseket a jóléti rendszer korrekcióját illetően. Hozzákezdenek, de véghezvitelétől visszarettennek a tömegek elégedetlensége, a nagy társadalmi ellenállás, tiltakozás láttán. Az érintett rétegek - mint ahogy az várható volt - fölháborodva fogadták a korábbitámogatások visszavonásának tervezeteit. A kilátásba helyezett intézkedésekben nem depaternalizáló lépéseket, hanem szerzett jogaiktól való megfosztásukat látták. És számon kérték a politikai vezetéstől nemcsak a klasszikus szocializmus jóléti ígéreteit, hanem a reformszocializmus új ígéretét is: a reform annak jegyében indult, hogy vége szakad a klasszikus rendszer okozta nélkülözéseknek és javulni fog az élet. A reform némi liberalizációt hozott magával, lazult a totalitarizmus szorítása, ami a korábbiakhoz képest nyitottabbá tette a nyilvános tiltakozások lehetőségét és veszélyét. Ugyanakkor a hatalmon lévő politikai vezetés mentalitásában benne volt, hogy „Nem akarunk többé utcai tüntetéseket vagy sztrájkokat látni! Ezt biztosítjuk azzal, hogy csökkentjük az elégedetlenséget.” Az elégedetlenség levezetésének egyik eszköztára volt a jóléti rendszerek kiépítése és fenntartása. ${ }^{14} \mathrm{~A}$ csöndet Kádár azzal érte el, hogy többet adott az embereknek anyagi téren. ${ }^{15}$ „Ez, az az átváltás (trade-off) - mondja Kornai -, amely egyfelöl a társadalmi nyugalom, másfelöl a fogyasztás és állami gondoskodás között van.” (Kornai 1996:183) „Valaminek változnia kell ahhoz, hogy semmi se változzon." - írta egykor Tomasi di Lampedusa. ${ }^{16}$ És valóban: az anyagi életkörülmények javításával meg lehetett örizni a hatalmi statusquót. Ennek tulajdonítható a reform azon jellegzetessége, hogy megpróbál elfordulni a korábbi hajszolt iparosítási politikától és nagyobb figyelmet szentelni a lakosság igényeinek. A hatalmi elit ezen szándéka erősítette az „életszínvonal-lobbi” befolyását és pozícióját a politikai arénában.

${ }^{14}$ A másik, a második gazdaság kifejlődésének a megtürése volt, a "húzd meg, ereszd meg” nadrágszíj-taktika mentén. Lsd. erröl bővebben Gábor R. - Galasi 1978, Gábor R. 1979, Laki M. 1980, Laki M. 1983, Tellér Gy. 1984, Tölgyessy P. 1984, Fekete J. 2002a

${ }_{15}$ "Az ország vezetői zsigereikben érezték, hogy ha valahol nagy dohogás volt, akkor oda kell dobni valamit." (Kornai 1996:184)

${ }^{16}$ Tomasi di Lampedusa (1984): A párduc. Budapest, Európa Kiadó, 425 old. (Idézi Fekete 1990:559) 
A reformszocializmus időszakában mindvégig nagy konfliktus feszült a hivatalos ideológia alapvető ígéretei és a rendszer tényleges gazdasági teljesítménye között. Sőt azígéret és a teljesítés közötti szakadék egyre nőtt a gazdasági növekedés lassulása, majd stagnálása következtében. Amikor a gazdaság felett gyülni kezdenek a viharfelhők - az előzőekből következően - a politikai vezetés nem a fogyasztás visszaszorításához nyúl, hanem a beruházások visszafogásához és külföldi hitelek felvételéhez. A módszer, amivel halogatni próbálják az életszínvonal drámai zuhanását, hosszú távon csak súlyosbítja a bajt. A beruházások csökkentése aláássa a későbbi növekedés alapjait. A nyugati kölcsönnel finanszírozott "gulyáskommunizmus”, illetve „frizsiderszocializmus” ára, hogy megindul az eladósodási folyamat. Az adósságszolgálat számláját majd a lakosságnak nyújtják be. Az állami költségvetés túlvállalásai krónikus deficitet idéznek elő, elindul az infláció. Végül az életszínvonal mégiscsak csökken, a jólét zuhan csak később, de nagyobb mértékben. A „tejjel-mézzel folyó Kánaán” helyett, a „hellyel-közzel csordogáló jóléti juttatások” után a reformfolyamat közepette elérkeztünk oda, ahol - Kornai szavaival - „... a terv plusz piac székei között a pad alá csúszva vergődnek a társadalom alsó rétegei”. (Kornai 1993/b: 481)

A fogyasztás erőltetésére azon az áron kerül sor, hogy közben: lelohad a növekedés (a paternalista gondoskodás fedezetére magas járulékokat és adókat kell kivetni, amely elszívja az erőforrásokat a növekedést közvetlenül szolgáló beruházások elől). Beindul az eladósodási folyamat. Az adósságszolgálat rövidesen rendkívüli terheket ró a lakosságra. Krónikus deficithez vezetnek az állami költségvetés folytonos túlköltekezései. Beindul az infláció stb. S mindez az áldozatvállalás, feszültséggerjesztés, bajnövelés, gondfokozás stb. szinte hiábavaló „fáradozás”, meddő áldozat a jólét oltárán. A rendszer a szűken értelmezett anyagi jólét tekintetében is elmarad a fejlődés ütemében, az életkörülmények minőségének javulásában - mind az ígéretektől, mind számos más, kapitalista úton járó ország teljesítményétől. A szolidaritás és a biztonság tekintetében is felemás a rendszer teljesítménye. Miközben nincsenek hajléktalanok az utcán, nagy a lakáshiány, társbérleti lakásokban és munkásszállásokban zsúfolódnak össze az emberek. A társadalmi biztonsági háló felfogja ugyan azokat, akik nem tudnak magukon segíteni, de ellátásuk a nyomorúságos és az elfogadható között ingadozik. Számos ponton messzire megy a nyugdíjrendszer, azonban a nyugdíj átlagszínvonala igen alacsony. A korábban nyugdíjba vonultak közül sokan nélkülöznek, ha nem nyomorognak. Miközben számos szolgáltatás ingyenes vagy irreálisan olcsó, nem lehet hozzájuk jutni vagy igénybe venni a krónikus túlkereslet, illetve a krónikus hiány következtében. A jóléti szolgáltatások széleskörűek, de sokszor rossz minőségűek. Az egészségügyi ellátás ugyan mindenkinek jár, a szolgáltatások minősége azonban erősen kifogásolható, és inkább csak elemi szinten, és csak az egyén alapvető ellátását nyújtja. Miközben ingyenes az egészségügyi ellátás, tömegesen elterjedt az orvosoknak és az ápolóknak fizetett „hálapénz”. (Losonczi 1986, 1989) Miközben igen magas az ezer lakosra jutó orvosok vagy kórházi ágyak száma, a lakosság körében sok a panasz, magas a gyermekhalandóság, alacsony a várható élettartam. Továbbá a munka biztonságát beárnyékolja, hogyáltalános munkakötelezettséggel jár együtt. A teljes foglalkoztatottság mögött pedig puha költségvetési korlát, beruházási éhség, expanziós késztetés áll. Összegezve: a probléma nemcsak az, hogy nincs miböl adni, és nemcsak az, hogy a kieröszakolt, illetve kölcsönkért fedezetnek túl nagy ára van, hanem az is, hogy amit adnak, az gyenge színvonalú, alacsony minőségü. Egyszóval: nem megfelelő.

A reformszocializmus (a „konstruktivista képződmény”, a „mesterséges agyszülemény”) - Kornai elnevezését használva - „koraszülött jóléti államot” hozott létre. Meg- 
fogalmazása mögött az a gondolat húzódik meg, hogy a törvénybe iktatott jogosultságok együttese, azaz mindaz együttvéve, ami az állampolgárnak jár az államtól, nem arányos a gazdaság teljesítőképességével, hanem nagyobb annál. A „koraszülött jóléti állam”-értelmezés lényege, hogy szoros összefüggés van egyfelől a gazdasági fejlettség, teherbíró-képesség, másfelől az életszínvonal, s ezen belül az életszínvonalnak az állami gondoskodás formájában juttatott része között. Ez az összefüggés empirikusan is megfigyelhetö, azaz a potenciál előbb-utóbb behatárolja a gondoskodási lehetőségeket. (Lásd erről bővebben Kornai 1993a, 1996.)

\section{A visszapillantás tanulságai: válaszok az induló kérdésekre}

Az eddigi fejtegetések során tehát e „koraszülött jóléti állam” születését és problémáját jártuk körbe. A történelmi tapasztalat azt mutatja, hogy a jóléti állam kiépítése akkor indult be, amikor az érintett országok éppen nehéz időszakban voltak, válságokkal, szegénységgel, háborús nyomorúsággal, éhezéssel küzdöttek. ${ }^{17} \mathrm{Ha}$ a jóléti állam kiépítésének időszakában létező egy före jutó jövedelmeket nézzük: ez (változatlan és összehasonlítható 1990. évi árakon számítva) Svédország esetében 3600-5000 \$ közötti egy före jutó bruttó nemzeti termék (GDP) volt 1932 és 1939 között; Nyugat-Európa egésze 5000-7000 \$ egy före jutó jövedelmet számlált, amikor általánossá vált a jóléti állam 1950 és 1960 között; a mediterrán Európa, valamint Közép- és Kelet-Európa 2000-7000 \$ közötti egy före jutó GDP-vel rendelkezett 1950 és 1973 között. (Berend T. 2003:1275)

A fejlett és koraszülött jóléti államok tekintetében tehát a lényeges különbség nem a starthelyzetben volt, hanem abban, ami az után történt. Nyugaton - ahol a piaci koordináció túlsúlya érvényesült - gazdasági fejlődés, hatékony növekedés zajlott, amely segítette azállamot szociális terheinek viselésében. Kelet-Európában, így Magyarországon is - ahol a bürokratikus koordináció túlsúlya érvényesült - hatékonyságcsökkenés, romló gazdasági teljesítmény, növekvő világgazdasági lemaradás, a fejlődés forrásainak kiapasztása mellett zajlott a növekvő jóléti állami szerepvállalás. Ebben az esetben egy alapvető, általános forrás, illetve fedezethiány melletti mértéktelen és aránytalan költekezés lehetetlenítette el a jóléti rendszert, igencsak terhes örökséget hagyva az átmenet időszakára.

Csehszlovákiában a Husák-rendszer lényegesen kedvezőbb makrogazdasági állapotot hagyott örökül, mint a Kádár-rendszer. Husák titkosrendőrséggel, az ellenzék börtönbe zárásával biztosította azt a csöndet, amit Kádár a „koraszülötti adakozással” ért el. Ennek ára is „,kizsebelol”" volt, vitathatatlan. De rosszabbat tett-e Kádár, mint amit Ceausescu tett? Aki „elvette az emberek elöl akár még a villamos áramot is, csak hogy jobb legyen az exportimport mérleg, és szinte az utolsó dollárig kifizethesse az adósságot. A zúgolódás ellen ott volt a titkosrendörség." (Kornai 1996:184)

Visszatérve, az arányt, a mértéket egy rendszer vonatkozásában sem lehet büntetlenül áthágni. Ahogy már Szókratész is megmondta:'Ha valamely összetételből bármely arány-

17 A Nagy Válság nyomorúsága, munkanélkülisége közepette Svédországban és az Egyesült Államokban a harmincas évek elején. Vagy közvetlenül a második világháború után Angliában 1945-48 között került sor az átfogó jóléti törvényalkotásra, amikor még jegyre osztották az élelmiszert és nélkülözött a lakosság. Felfutása egész NyugatEurópában a háborús pusztítás utáni újjáépítés időszakában, az ötvenes években zajlott. És Magyarországon is a háború után, nyomor és zürzavar közepette indult hódító útjára. 
ban is hiányzik a mérték, illetve a szimmetria, úgy az alkotóelemekre és az összetételre egyaránt pusztulás vár.'

Ha már itt szóba hoztuk a gazdasági fejlődés kérdését, füzzünk ehhez rövid kiegészítést. Széles körben elterjedt az a feltételezés, hogy a szociális terhek állami vállalása hátrányos a gazdasági növekedésre és rontja a versenyképességet. Ha ebből a szempontból összehasonlítjuk Nyugat-Európát az Egyesült Államokkal, akkor a kérdésre a következő választ kapjuk: Az egy före jutó jövedelmét a jóléti Nyugat-Európa háromszor olyan gyorsan növelte 1950 és 1973 között, mint az Egyesült Államok. (Utóbbi 60\%-kal növelte azt, míg előbbi ugyanezen időszak alatt közel két és félszeresére.) A gazdasági növekedés tekintetében 1950 és az ezredforduló között az USA 286\%-os, míg Nyugat-Európa 390\%-os növekedést produkált. A munka termelékenységi szintjét nézve Nyugat-Európa az amerikai feléről 1970-re annak 70\%-ára fokozta, majd a század végén elérte annak szintjét. (Berend T. 2003:1276) Ha azonban Svédországot vetjük össze az európai OECD országokkal, akkor azt látjuk, hogy 1970 és 1996 között az egy foglalkoztatottra jutó GDP éviátlagban kisebb százalékkal nő (1,45\%), mint az európai OECD-országok csoportjában $(2,02 \%)$. A termelékenység növekedési ütemében is elmaradt a jóléti mintaország. Ehhez a tényhez azonban hozzá lehet füzni azt is, hogy a termelékenységnövekedési ütem részben azért volt visszafogott a svéd gazdaságban 1970 után, mert nagy részarányt képviselt az alacsony termelékenységnövekedést mutató állami szektor - egyes számítások szerint 1970 és 1992 között negatívat (Lindbeck 1998a:67-69).

Tehát, óvatosan a kategorikussággal. És ne csak szembe nézzünk a tényekkel, hanem nézzünk mögéjük is. A tények makacs dolgok. Eszembe jut Gyurkovicsnak egy megjegyzése, hogy 'semmi sem hamisíthatja meg úgy a valóságot, mint a tények.' Részben erre is gondolva, részben arra is, hogy mi, kelet-európaiak jól tudjuk - tehát nem is vonjuk kétségbe - hogy milyen hátulütői vannak a bürokrácia kiterjedt müködésének, hogy a kormányzati intézkedéseknek jócskán vannak nem szándékolt mellékhatásai (az ún. származékos externáliák), hogy milyen súlyos következményei vannak az inputok és outputok függetlenedésének, hogy milyen hatással jár a nyomásgyakorló csoportok létezése és beépülése a politikába. Tehát ismerjük azokat a jelenségcsoportokat, amelyek veszélyeire és buktatóira a jóléti állam ellentmondásai kapcsán figyelmeztetni szoktak. ${ }^{18}$ Ezek a kritikák megalapozottak és valósághűek, csakúgy, mint a jóléti állam egyéb kockázatait hangsúlyozó bírálatok: a „tanult gyámoltalanság”, a veszélyeztetett makroegyensúly, a kormánytisztviselők magatartási inerciái, a piaci kockázatok helyettesítése politikaikockázatokkal. ${ }^{19}$ Mindezek valóságos gátjai a jóléti állam fejlődésének és hátráltatói a gazdaság hatékony működésének. Pusztán a kategorikusság és az elhamarkodott kijelentések ellen kívánok szót emelni ezzel a kitérővel. Nehogy félrevigyenek, rossz vágány felé tereljenek bennünket evidenciaként kezelt, de megkérdőjelezhető kijelentések. Csak alázatot szeretnék kérni a valóság iránt, nagyobb óvatosságot és több nyitottságot.

${ }^{18}$ Statikus szemléletben vizsgálják a kormányzati kudarcokat Le Grand (1999), továbbá Niskanen, William A. (1971): Bureaucracy and Representative Government. Chicago. Aldine Atherton. (Idézi Szabó 2000:222),

Wolf Jr., Charles (1988): Markets or Governments: Choosing between Imperfect Alternatives. Cambridge, Mass.: MIT Press (Idézik Szabó 2000:222-225, Le Grand 1999:151-154), valamint Friedman, Milton (1979): Capitalism and freedom. Chicago, University of Chicago Press. (Idézi: Szabó 2000:223).

${ }^{19}$ Dinamikus szemléletben vizsgálják a jóléti állam ellentmondásait, például Barr (1999), továbbá Niskanen, William A. (1996): The culture of poverty: CATO Journal, vol. 16. Issue 1. Spring/Summer. (Idézi Szabó 2000:226), valamint Assar Lindbeck munkái is. 
A másik induló kérdésre rátérve: a kormányok, politikusok és a társadalmi jólét viszonyát illetően a történelmi tapasztalat (a tényleges indíttatás) áttekintése visszaigazolta Kornai, Buchanan és mások vélekedését. A jóléti állam kiépítése a politikusok, kormányok részéről nem cél, hanem eszköz volt, amelyeket hatalmi pozíciójuk erősítése, legitimációja, megvédése vagy megszerzése céljából használtak fel itt is, ott is, ${ }^{20}$ vagy az adott politikai irányzat vagy rendszer felsőbbrendűségének igazolására más irányzatokkal vagy rendszerekkel szemben. ${ }^{21}$ Volt, amikor a jóléti állam visszaszorítása, támadása szolgált eszközül a politikusok számára hatalmi ambíciójuk megvalósítása, a hatalom megszerzése céljából. ${ }^{22}$

A tapasztalt politikusi viselkedésből, továbbá az ehhez társuló „hiperérzéketlenségü kből”, illetve „hiperérzékenységükből” ${ }^{23}$ le kell vonnunk a konzekvenciát. Van egy kínai mondás, mely szerint „A házasságot szilárdabb alapra kell helyezni, mint a szerelem.” $\mathrm{Az}$ állam szerepvállalását, illetve a gazdaság és társadalom sorsát szilárdabb alapra kell tenni, mint az éppen hatalmon lévők éppen aktuális, többnyire szüklátókörü, rövid távú hatalmi érdeke és törekvése által létező ingovány. A problémát érzékelve ezt a feladatot szeretné megoldani a Buchanan nevéhez kötődő iskola is, amely szerint célszerű lenne korlátozni a politikusok mérlegelési jogát és a választókra bízni a döntést nagy kérdésekben. „Ez - az alkotmányos politikai gazdaságtanként is jelentkezö - irányzat arra törekszik, hogy a döntéshozókat minél több, általuk nem fölülbírálható, magas jogállású elöirás szorítsa az amúgy is szükséges, józan észt követelö döntésekre. Ilyen lehetne például a kiegyensúlyozott költségvetés elöirása (ami az USA tagállamaiban évtizedek óta bevált gyakorlat), az államháztartási deficit jegybanki «áthidalásának» a tilalma, vagy épp az EU-bürokrácia szabályalkotási dühét keretek közt tartani próbáló EU-alkotmány kialakításának kísérlete." (Bara-Csaba-Gedeon 2000:37)

Ha már a politikusi viselkedésről szó esett, meg kell említeni azt a szerepzavaros állampolgári viselkedést is, amely szorosan kapcsolódik a biztonság kérdéséhez és gyökerei az áttekintett időszakra nyúlnak vissza. A második világháború után Magyarországon és a többi kelet-európai országban is tönkre tették a tulajdonhoz kapcsolódó magatartásformákat. Ezzel együtt az egyénből „kiirtották” nemcsak a tulajdon ról, hanem azönmagáról, a saját maga biztonságáról való gondoskodás mintáját is. Elvették tőle az ehhez szükséges anyagi eszközöket és lehetőségeket. Ezen túlmenően megszűnt számára az a kulturális hagyomány, viselkedési norma, szokás, jogi, intézményi keret stb., amivel megoldhatta volna önmaga számára, hogy ha muszáj, ha rászorul, kövesse azt az útmutatást, hogy „segíts magadon, az Isten is megsegít”. Majd amikor ezt a rákényszerített külső és központi gondoskodást felmondta az állam, az egyén a korábban rákényszerített gyámoltalansága miatt támasz nélkül maradt. A szociálpszichológiai tapasztalatok fényében: biztonság egyenlő támasz plusz bizalom. Az egyén számára nemcsak a támasz, a bizalom is odalett. Már nemcsak a politika volt bizalmatlan vele szemben. A gyanakvás légkörében nevel-

${ }^{20}$ Gondoljunk csak Bismarckra, a francia politikusokra a harmadik köztársaságban, Rooseveltre vagy Kádárra.

${ }_{21}$ Úgy mint a világi gondolkodás/köztársasági eszmék fölényét a vallásos gondolkodás/egyházi befolyás fölött; a demokratikus eszmék felsőbbrendüségét a szélsőséges jobb- és baloldali populista irányzatok fölött; a demokrácia fölényét a diktatúrával szemben; a jóléti elkötelezettség fölényét a háború és erőszak iránti elkötelezettséggel szemben; a jóléti állam felsőbbrendüségét a hatalmi állam fölött; az emberarcú kapitalizmus fölényét az egyenlösítő szocializmussal szemben; vagy éppen fordítva, az igazságos szocializmus fölényét az igazságtalan kapitalizmussal szemben.

${ }^{22}$ Az "adóztató-költekezó állam" helyett a "gazdaságot dinamizáló állam" igéretével nyert a választásokon Margaret Thatcher és Ronald Reagan.

${ }^{23}$ A fogalmak kifejtését lásd Fekete 2002:208 
kedett egyén is elvesztette a bizalmát a politikában, az államban, hiszen az nem tartotta be ígéreteit, nem teljesítette felé vállalásait. Ha nincs támasz, se bizalom, akkor biztonság sincs. E teljes bizonytalanság közepette szinte törvényszerü, hogy nemcsak az „újtól”, hanem minden „mástól” is fél az egyén. Az átmenet időszakában emellett ráadásul rá kellett hangolódnia egy addig nem gyakorolt, nem is tanult, olykor még távolról sem ismert, idegen szerepkörre, a piaci magatartásra is. Ezek összhatásaként az egyén szerepzavarokkal terhelten, emocionálisan és nem tiszta fejjel, racionálisan gondolkodva fogadja az állam újabb és újabb racionalizáló korlátozásait. Egymástól eltérő nyelven beszélnek, és nekik kellene szót érteniük egymással. ${ }^{24}$

Mit lehet tenni a házunk táján ebben a helyzetben, amikor e meglévő bizonytalanságot növelheti, és sokak számára az élet minőségének további romlását jelentheti az állam jóléti kiadásainak drasztikus csökkentése, az eddigi jóléti kiadások szintjének fenntartása viszont olyan nagy adózási teherrel jár együtt, amely kedvét szegi a beruházóknak és ezáltal visszatartja a gazdasági növekedést? Márpedig a jóléti szolgáltatások biztosításához ez nélkülözhetetlen. „Egy fiskális csapdávalállunk szemben” - összegezi Kornai. „Nincsen kard, amellyel el lehet vágni ezt a gordiuszi csomót - mondja. A kibogozásához türelem és tapintat kell" (Kornai 1993a:140, 141). A megoldáshoz az önkéntesség és a szabadság vezérelvét ajánlja: a profitorientált és nonprofit biztosítótársaságok és nyugdíjintézetek decentralizált hálózatának előmozdítását, amelyhez önként csatlakozhatnak munkaadók és munkavállalók, továbbá hogy a jövőben az egyén kapjon mind nagyobb lehetőséget és mozgásszabadságot, hogy válasthasson a különböző jóléti ellátási formák között. Leszögezi azonban, hogy adván az induló helyzet, ehhez a végállapothoz csak fokozatosan lehet közeledni. Nem lehet azokat kész helyzet elé állítani, akiknek nincs módjuk valóságos választásra. (uo.)

Számtalan és sokféle szempont van, amit mérlegelni kell(ene) a jóléti rendszer átalakítása során. Ilyen többek között a méltányosság elve is. És fontos, hogy ne csak a döntéshozók, hanem a társadalom nagy része is méltányosnak tartsa a változtatásokat. Erre hívja fel a figyelmet Nagy András (1998:476) is. E nélkül nehéz elfogadtatni, így kivitelezni is a szükséges megszorításokat. Ezt a realitást szem elött tartva például a teljes öngondoskodást a közeljövőben még elvileg se lehet fölvetni. Hogy mennyire predeterminál a szocialista örökség? A társadalmi várakozások által - amint az eddigiek mutatják - nagyon is. Ezek a genetikai kódok ott vannak még a társadalom zsigereiben, és akarva-akaratlanul hordozzák azt a „koraszülött jóléti programot”, amitől azonban mégis csak muszáj szabadulni.

„Vergődés és remény” között hányódunk, ahogy ezt Kornai egyik könyvének címével is kifejezte (Kornai 1996). Ezt a hánykolódást enyhítheti:

- a tényleges diagnózis, a problémák valódi tisztázása és leltára - elmélettörténetileg is. (Szamuely L. - Csaba L. 1998);

- a célkitűzésekkor annak belátása, hogy „nincs jó rendszer, csak jobb és rosszabb jóléti rendszer van" (Nagy 1998:476);

- a kalkulálás azzal a tényezővel, hogy „nem racionális megfontolások alapján mennek végbe a változások" (Nagy 1998:476), hanem az egyes társadalmi rétegek ér-

${ }^{24} \mathrm{Az}$ átmenet problémáit, a honnan hová kérdését taglalva. Nagy András is kiemeli az "eltorzult polgárosodás" gondját. (Nagy 1993) 
dekei, érdekérvényesítési képességei, erőviszonyai és hatalmi pozíciói alapvetően befolyásolják a változtatások kimenetelét;

- kölcsönös kompromisszumkészség tanúsítása a szükségessé vált reformfolyamat mentén;

- annak tudomásulvétele és józan elfogadása, hogy a létező problémák valódi rendezésére nincs gyors megoldás.

Az átmenet nehézségeiről sokan és sokat publikáltak. Témánk szempontjából és itt is csak jelzés értékűen Tóth I. Gy 1994, Köves A. - Szamuely L. 1997, Kornai J. 1998, Csaba L. 2000b, 2002 és Nagy A. 2001 munkáit említjük. Az átmenet országaiban az eddigi átalakulásokat sommásan nem lehet se kudarcként, se sikertörténetkéntértékelni. Jóval inkább a „sokszólamúság” illik rá (Csaba L. 2000b), s ez az „összhangzattan” további árnyalatokkal szélesül aszerint, hogy az eddigi kihívások mellett hogyan tudnak majd megbirkózni napjaink újabb feladataival, azokkal, amelyek a Nyugat számára is nagy kihívásokat jelentenek, úgymint globalizáció, demográfiai változások, informális társadalom, ökológiai problémák.

\section{A jóléti állam válsága Nyugaton a kilencvenes években és napjainkban}

A nyolcvanas években - ahogy ezt Eric Helleiner nevezte - valóságos „deregulációs verseny" indult meg a világban ${ }^{25}$,és a kilencvenes években uralkodóvá vált a jóléti állam általános válságának irányvonala is, mind tudományos mind politikai berkekben.

Alber ${ }^{26}$ egy 1988-ban közreadott cikkében, amelyben empirikusan összeveti a nyugateurópai, észak-amerikai és japán jóléti kiadások alakulását, még arra a végkövetkeztetésre jutott, hogy a negatív jelenségek nem a jóléti állam válságtünetei, nem a jóléti intézményrendszerek müködésének óhatatlan következményei, hanem ezeknek az intézményeknek az új történeti makrokonstellációhoz való alkalmazkodási problémáinak a következményei. A kilencvenes években az intézményrendszer problémáját Szabó Katalin már úgy értékeli, hogy az „a jóléti rendszer, amely az ipari társadalmak invenciója volt, nem alkalmas arra, hogy az információs társadalom szociális problémáit kezelje. A gazdasági alap radikálisan különbözik az ipari társadalmétól, s ezért egyre nehezebben férnek vele össze a jóléti rendszer meglévő, évtizedekkel korábbi állapotokat tükröző intézményei." (Szabó 2000:229)

Vannak, akik a válság okát a hatalmas technológiaváltással, a „harmadik ipari forradalommal" indokolják. Mások azokkal a világgazdasági változásokkal hozzák összefüggésbe, amelyet a Kondratyev-ciklus magyaráz, illetve az, hogy a világ e ciklus hanyatló ágába érkezett. Sokan a globalizációval érvelnek. Ezzel kapcsolatban Steen Mangen azt állítja, hogy e világgazdasági változások „alapvetöen aláásták ... a jóléti elvek, a társadalmi szolidaritás, egyenlöség és egyetemesség érvényesitését. ${ }^{27}$ Többen a népesség elöregedését, a család hanyatlását, a tömeges munkanélküliséget hangsúlyozzák (Gota Esping-Andersen 1999). Akadnak, akik a finanszírozás problémájában látják a bajok gyökerét. Ladányi János és Szelényi Iván (1997:72,74) szerint az okok mélyebbre nyúlnak, a rendszer belső

25 Idézi Berend T.2003:1278

${ }^{26}$ Alber, J. (1988): Is there a crisis of the welfara state? Cross-national evidence from Europe, North America and Japan. European Sociological Review, Vol. 4. No.3. 181-203. (Idézi Csaba I. - Tóth 1999:37)

27 Idézi Berend T. 2003: 1273 
logikájából adódnak, és annak a hatalmi egyensúlynak a felborulására vezethetők vissza, amely korábban a rendszer alapját adta.

Szabó Katalin ellenben úgy véli, hogy „a jóléti állam ... nem eredendő szervi bajai miatt haldoklik ... hanem azért, mert a gazdaság, amelyre a jóléti felépitmény alapozódott, megváltozott... Az új gazdasági környezetben a jóléti állam a maga klasszikus formájában idegen test ... A kilökődési reakciókat természetesen erösítik a jóléti rendszer eredendö bajai, de a jóléti állam lélekharangját igazában az információs társadalom kondította meg." (Szabó 2000: 229-230). A 21. század hajnalán zajló „,csendes forradalomról”, „,technológiai rendszerváltásról” ír Szabó Katalin és Kocsis Éva (2002). A tőkés gazdaság fejlődésének dinamikus változásaira helyezi a hangsúlyt az a nézet is, amely a fordizmus válságára vezeti vissza a jóléti állam válságát. ${ }^{28}$

Berend T. Iván egy most publikált cikkében (2003:1278) arra az álláspontra helyezkedik, hogy „a gazdasági és társadalmi változások a jóléti intézmények számos elemének újragondolását és reformját követelik meg, ami azonban nem vonta és vonhatja kétségbe az intézmények életképességét és alkalmazkodni tudását." Úgy látja, hogy a jóléti állam válságának koncepciója és felszámolásának sürgetése a „piaci fundamentalizmus” világnézetéből fakad, amelyben a jóléti állam a bajok forrása, megszüntetendő anomália. Berend T. szerint viszont, ezzel ellentétben „a jóléti állam a 20. század legnagyobb társadalmi vívmánya". (U.o)

Assar Lindbeck (1998b:69) a svéd modell alapos és körültekintő elemzését e szavakkal zárja: „Nem tudjuk még, hogy Svédország, mely úttörő volt a sokoldalúan gondoskodó jóléti állam kiépitésében, úttörölesz-e annak reformjában és felszámolásában is. Elöfordulhat az is, hogy azok az értékek, ideológiák, eröviszonyok, mechanizmusok, melyeknek összjátéka eredetileg létrehozta a modellt, újra feléleszthetik a jövőben a korábbi politikát vagy ennek egy új változatát."

A jóléti állam jövőbeli sorsát is általánosan az határozhatja meg, hogy mi fog történni az Európai Unióban; milyen jóléti reform irányzatok lesznek, ezek hatékonyak és tartósak lesznek-e; hogyan alakul a politikai erőviszonyok és a gazdasági mechanizmus összjátéka; mit eredményeznek a korlátozások korlátai; merre halad majd a globalizált világ; milyen válaszok születnek napjaink nagy kihívásaira. Sommázva azt mondhatjuk, hogy eddig háromfajta kormányzati reakciót figyelhettünk meg a kialakult helyzetben:

- visszatáncolást, a jóléti állam visszabontását („vadkapitalizmus”),

- vegetálást (vergődést) a romokon,

- az esélyteremtő állam kibontakozását, elindulást egy új társadalmi megegyezés felé.

A második reakciót rögtön ki is zárhatjuk: nem útkeresés, hanem a halogatás útja. Nem megoldás: vergődés.

Az első a „reganomics" vagy „thatcherizmus" útkeresése, amely leépítette ugyan a túlélt, elavult jóléti intézményeket, de alkalmatlannak bizonyult a változásokat követő új intézmények kiépítésére. A jobboldali-konzervatív kormányok „minimális állam” jelszava elégtelen volt a megoldáshoz. Az információs társadalom kiépülése számos olyan követelményt támaszt, amelyek teljesítéséhez aktív állami közremüködés szükséges. Állam

${ }^{28}$ Lásd például Barbier, J-C. - Nadel, H. (1996): L'évolution des systems de protection sociale en Európe. Revue Francaise des Affaires Sociales. 1:25-55; Saillard, Y. (1995): La régulation, I'état des savoir. Párizs La Découverte. (Idézi Nagy 1998:459) 
nélkül aligha képzelhető el az oktatás, az információs társadalom infrastruktúrájának a kiépítése - amelyhez az erőforrások koncentrálása kell.

A neokonzervatív választ és annak kudarcát, ha egy kicsit közelebbről megnézzük Nagy-Britannia példáján, hasznos tapasztalatokhoz juthatunk a jövőre nézve. Ideológiájuk szerint a jóléti állam túl sokat költött a felduzzasztott állami bürokráciára, túl magasra növelte az adóterhet, és túlzott szabályozással feleslegesen korlátozta a piac müködését. Ráadásul széles rétegeket tartott el szociális segélyekkel. Az „adóztató-költekező állam” helyett ők a „minimális állam” koncepcióját hirdették meg (Ladányi - Szelényi 1998:73).

A szociálpolitika új-jobboldali programja a kötelező és univerzális rendszerek lebontását és a reziduális jóléti állam megteremtését javasolja. A szociális szolgáltatások működtetését, amennyire csak lehet, a piacra bízza. Az állami intézményeknek csak kiegészítő szerepet szán. Figyelme csak a legszegényebbekre terjed ki. A redisztribúció nem szolgálhat egyenlősitő célokat, csupán a legalapvetőbb létfenntartási szükségletek kielégítését biztosíthatja. A tradicionális kulcsszavak helyett (mint pl. egyenlőség, szolidaritás, közösségiség, szociális jogok) új jelszavak lettek: szabad verseny, önsegítés, szabad választás, személyes függetlenség, magánvállalkozás. Napirendre tűzték a jóléti állam radikális privatizációját (Csaba I. 1991:81-82).

A program mögött olyan világkép húzódott meg, ahol az egyik oldalon az idealizált tökéletes piac, míg a másikon a fogyatékos állami szféra helyezkedett el. A „hibátlan piac” és a „minimális állam” illúzióját szétoszlatták a gyakorlati tapasztalatok. Arra a józanságra intve, hogy a ténylegesen létező piacot vessük össze a valóságos nem piaci intézményekkel, a tökéletlen piacot a kormányzati elégtelenségekkel, fogyatékosságokkal. Ebben a gondolkodási keretben nemcsak megszűnne a „süketek párbeszéde”, hanem ekkor válhat reálissá az egyes intézményi alternatívák közötti választás, ekkor van realitása a különbözö típusú előnyök és hátrányok összevetésének. ${ }^{29}$ Végül, a hangzatos kormányzati szónoklatok ellenére nem a jóléti állam radikális privatizációja zajlott a gyakorlatban, hanem egy jóléti vegyesgazdaság keretei között a magánszektor részleges térnyerése (Csaba I. 1991:96).

A Thatcher-kormány szociális kiadások ellen indított dühödt offenzívájából lényegében a Wagner-törvény felfüggesztése maradt meg. A kezdeti radikalizmushoz képest a ténylegesen végbement változások nem lettek oly drámaiak. „...ha szemügyre vesszük Nagy-Britannia szociális kiadásait Thatcher miniszterelnök kormányzása alatt, azt látjuk, hogy ezek összege reálértékben nemhogy csökkent, hanem évröl-évre növekedett; a lakásra, egészségügyre és személyes szociális szolgáltatásokra, társadalombiztositásra, valamint az oktatásra forditott kiadások az 1989/1990-es költségvetési évben együttesen 18\%-kal haladták meg az 1978/1979-es szintet" (Csaba I. 1991:84). Kétségtelenül történtek jelentős korlátozások is. Megszigorították a szociális szféra költségvetési korlátját. Egyes, korábban ingyenes szolgáltatásokra díjszabásokat vezettek be, másoknál elóállításukbólvonult ki az állam, átruházva másra az ezzel kapcsolatos felelősséget is.

Történt azonban egy más irányú változás is. A „mennyit” kérdése mellett a „hogyan” problémája is előtérbe került a szociálpolitikában. A „hogyan” újszerű kérdésére a konzervatívok sok esetben dogmák és elöítéletek szülte válaszokat adtak (Csaba I. 1991:96).

\footnotetext{
29 Például a magánegészségügy hajlamos a betegek túlkezelésére, míg az állam alulszolgáltatásra. Vagy a piaci megoldás elmaradhat a közgazdasági optimumtól, ha a kínálat monopolisztikus, ha a fogyasztói választás lehetősége korlátozott. Továbbá, a szociális szférában a profitmaximalizáló vállalkozás nem garantálja minden esetben a tágabb értelemben vett hatékonyságot. Egyes univerzális jóléti rendszerek tehát nemcsak a szociális integráció, hanem a gazdasági hatékonyság érdekeit is szolgálhatják.
} 
Elindultak azonban olyan reformkísérletek is, amelyek megmutatták, hogy számos alternatíva létezik a szociálpolitikában. És eközben olyan újítások is születtek, amelyek már a paradigmaváltás irányába mutattak. A jóléti kérdés újszerű gyakorlati megközelítése tükröződik a kilencvenes évek Angliájában is. A konzervatívok által hátrahagyott növekvő társadalmi egyenlőtlenség erősödő problémája is ilyen irányba sarkall. A jövőben kiderül, hogy az „esélyteremtő állam” koncepciója felé történt nyitásnak lesz-e folytatása.

Szélsőséges, hamis véglet volt a neokonzervatívok „államtalanítási” kísérlete. Ki is fulladt. És szélsőséges, hamis véglet volt - csak éppen a másik póluson - a svéd szociáldemokraták „államhatalmassági” kísérlete is a hatvanas évek közepétől a kilencvenes évek elejéig. E modell jótékonykodási konstrukciója mélyrepülésbe vitte a gazdaságot, ugyanakkor elégedetlenné tette a társadalmat. A svéd modellben a kormányzat alapvetö törekvése volt, hogy a spontán piaci mechanizmusokat politikai és adminisztratív döntésekkel helyettesítsék. Úgy gondolták, hogy a gazdaságpolitikai vezetés majd kiegyenlíti a piacok és gazdasági ösztönzők szerepének meggyengítését - szelektív pénzügyi támogatással és beavatkozással.

A „hibátlan állam” vagy inkább a „mindentudó állam” illúzióját itt is szétoszlatta a gyakorlati tapasztalat. „A beavatkozás beavatkozást szült.” (Mintha ez ismerős lenne Kelet-Európában is.) Csökkent a gazdasági növekedés. Az egy före jutó GDP-t nézve a nemzetközi rangsorban 1970-ben még a 4. helyen állt Svédország, 1990-ben a 9., 1995-ben már a 16. helyre csúszott vissza (Lindbeck 1998a:68).

Mi eredményezte mindezt? Assar Lindbeck - a helyzet kiváló ismeröje - szerint környezeti és modellbeli okok egyaránt. Az exogén hatások olyan változások voltak, amelyek minden fejlett országot érintettek (technológiai robbanás, elöregedés, globalizáció). Az endogén okok: a politikusok viselkedése (mint legfontosabb belső ok), az ösztönzés eltorzítása, a verseny gyengítése, a bérarányok rugalmatlansága, az erkölcsi kockázat (adó- és juttatási csalások ${ }^{30}$ ). És belső ok volt az a mód is, ahogy a modell a sokkokra válaszolt.

A megoldást Lindbeck az intézmények és politikák megreformálásában látja: az 1991ben elkezdett, majd a hatalomra került jobbközép kormányzat által is (1991-1994 között) továbbvitt reformok (adóreform, antiinflációs gazdaságpolitika) folytatásában. A kilencvenes évek elején megszünt a teljes foglalkoztatottság. Fokozódtak a jövedelmi egyenlőtlenségek. Megnyirbálták a jóléti juttatásokat. A kilencvenes évek reformjai után a svéd jóléti állam már nem ugyanaz a jóléti állam, amely korábban volt, és amely „a bölcsőtől a sírig" gondoskodott állampolgárairól. Lindbeck ugyan aggódva szemlélte még, hogy az 1994-ben, a hatalomba visszakerült szociáldemokraták - több reformintézkedés fenntartása, sőt továbbfejlesztése mellett - egyes reformokat visszafordítottak, újra emelték az adókat és járulékokat, de bízott abban, hogy az 1995-ben elnyert EU-tagság megerősíti az elkezdett reformfolyamatot, és Svédország, ahogy ő fogalmazta, újra „normálisabb” nyugat-európai országgá válhat, olyanná, mint amilyen volt, mielőtt hozzákezdtek volna a radikális kísérletekhez a hatvanas-hetvenes évek fordulóján. És mindaz a rossz, ami e három évtizedben történt, csak egy közjáték, rövid történelmi epizód marad (Lindbeck 1998b:68-69). Ha korábban a jóléti állam „eszköz” volt a politikusok kezében, akkor most azt mondhatjuk, hogy a svéd politikusok kezében ,játékszer” volt e három évtizedes kísérleti időszak alatt.

30 Svédország a "csalók nemzetévé vált" - jelenti ki Myrdal, Gunnár(1978): Dags för ett Bättre Skattesystem. Ekonomisk Debatt, 6(7). 493-506. (Idézi Lindbeck 1998/a:84) 
Csak röviden pillantsunk rá, mi a helyzet egy ún. „normálisabb” nyugat-európai országgal, Franciaországgal a kilencvenes években?! Itt teljes az egyetértés a reformok sürgetésében. A kilencvenes évekre kiéleződött feszültségek hatására nélkülözhetetlenül szükségesnek tartják a reformokat a nagymérvü munkanélküliség és a szegénység kezelése terén. További érv a reformok mellett, hogy a vállalatokat terhelö igen magas társadalombiztosítási járulékok veszélyeztetik a nemzetközi, sőt egyes esetekben már a belföldi versenyképességet is, és ezek csökkentésére mindenképpen szükség van. Ezért a javaslatok arra irányulnak, hogy csökkentsék a vállalatok terheit. A szociális költségek nagyobb részét fizessék az alkalmazottak. A biztosítási elvet terjesszék ki. Ezáltal a szolgáltatások váljanak „személyre szabottabbá” és nyújtsanak bővebb választékokat. Egyes szakértők attól tartanak, hogy a szociálpolitika ilyen liberális átalakítása a társadalom hármas rétegződésére vezetne: az alul lévők a segélyektől függnének, a középen lévők lennének a társadalombiztosítás fő kliensei, a társadalom csúcsán lévők pedig a piacon biztosítanák saját védelmüket (Nagy 1998: 462). A nyugdíjrendszer finanszírozhatatlanná válásának felismerése vezetett az 1993. évi nyugdíjreformhoz. Ezt követte 1995-ben az egész társadalombiztosítási rendszer reformjavaslata, amelyet a nemzetgyűlés elfogadott. Ebben a kormány támogatta az egyéni és csoportos önkéntes megtakarításokon nyugvó nyugdíjrendszerek létrehozásátés elterjesztését. Erre azintézkedéstervezetre hatalmas társadalmi megmozdulás és közalkalmazotti sztrájk válaszolt. Ez felhívja a figyelmet arra, mennyire korlátozottak a kormányok gazdaságpolitikai manőverezési lehetőségei, és arra is, hogy a jóléti rendszerek átalakítását nem lehet sem finanszírozás-technikai kérdésre leegyszerüsíteni, sem egyes (biztosítási, szolidaritási) elvek érvényesülésének arányváltozásaira. Új „társadalmi szerződés” megkötésére van szükség (Nagy 1998).

És ez el is vezet bennünket a harmadik reakcióhoz, az „esélyteremtő állam” koncepciójához. Kidolgozói szociológusok (talán nem véletlenül), Ladányi János és Szelényi Iván (1997). A már említett hamis végletek helyett olyan állam kiépítését javasolják, amely alapvetően a termelés feltételeinek javítása érdekében avatkozik be a gazdaságba. És nem a már megtermelt javak újraelosztása miatt. A megvalósításhoz egy „új társadalmi szerződés" megkötését sürgetik a társadalmi és gazdasági élet mai szereplői között. Olyan megállapodást, olyan „új New Deal”-t javasolnak, amely egyaránt válaszol korunk gazdasági és társadalmi kihívásaira. ${ }^{31}$ Véleményük szerint ennek kimunkálásához az Európai Unió is jó terep lehet az állami bürokrácia és technokrácia számára.

Hangsúlyozzák, hogy az esélyteremtő állam „gazdasági növekedést és profitot generáló állami beruházásaival kedvébe járhat az üzleti életnek. A növekvő állami adóbevételekkel (amelyek tartós gazdasági növekedés esetén nem kell, hogy magas adókulcsokkal járjanak együtt) képes lehet leszerelni a magas adóktól rettegö gazdagokat, és hatékony jóléti politikájával meggátolni a legszegényebb társadalmi csoportok leszakadását" (Ladányi-Szelényi 1997:77). Ez az új verzió, szemben a régiekkel, az egyik probléma megoldását nem a másik rovására oldja meg. ${ }^{32}$

Az esélyteremtő állam általános jellemzői Szabó Katalin (2000:238) összefoglalásában: a pénzt szűken költijólétiintézményekre,sokkalinkább esélyteremtőberuházásokra;csak

${ }^{11}$ Szemben a szociáldemokráciával, amely döntően csak szociális téren törekedett eredményeket elérni. És szemben a neokonzervatívokkal, akik szeme elött csak a gazdaság modernizálása lebegett.

32 Például az oktatási beruházásokkal egyszerre ad esélyt a fiataloknak és a gazdasági növekedésnek. Az oktatás, a képzés támogatása egyben a szociális védelem legjobb módja is. A képzés segítése elömozdítja a modern atipikus foglalkoztatási formák terjedését is. 
a rászorulókat támogatja (leszámol az univerzalizmussal); az üzleti világnak is kedvez a beruházások és az oktatás ösztönzésével; kikapcsolja a tanult gyámoltalanságot (a negatív ösztönzőket); adekvát az új társadalmi struktúrával; felismeri a globalizáció kihívásait és válaszol rájuk; ellenáll a populista szirénhangoknak.

\section{Összefoglalás helyett}

Az egyes nyugati demokráciák részéről megfigyelhető bizonyos nyitás az esélyteremtó állam felé. Elgondolkodtató, hogy ezek elsősorban miért pont az Egyesült Âllamok és Nagy-Britannia? Az az alapkérdés is megválaszolásra vár, hogy mekkora gazdasági potenciálhoz mekkora jóléti állam tartozhat? És ha az adott esetben ez kisebb, mint a társadalmi igény, akkor hogyan van esélye az esélyteremtő állam kibontakozásának? E tekintetben félő, hogy nemcsak itthoni „koraszülött viszonyaink” és a többi rendszerváltó ország sajátos hátrányai késztetnek óvatosságra az optimista várakozásokat illetően, hanem általánosabb értelemben is nehéz bizakodó prognózist adni az esélyteremtő állam közeli megvalósulásának esélyéröl.

Platón kérdése tehát ma is aktuális: hogyan kell berendezni az államot...? Aki a kormányzati kudarcokat látva visszavonulót fúj azállamnak, az is belátja az állam szükségességét, fontosságát. Még a piachívő Hayek is elismerte, hogy nem lehetünk meg nélküle. Az állam nélküli társadalom - utópia. De az államot beépített mechanizmusokkal, intézményekkel korlátozni és kontrollálni kell. Azzal, hogy Kornai azt állítja, a koraszülött jóléti állam nem életképes és nem tartható fenn, még nem tagadja meg a jóléti államot magát is. Ezen intézmény bírálói közül sokan vallják, amit ő is, hogy „A jóléti állam kialakulása a modern civilizáció egyik nagy vívmánya, amelyet meg kell ôrizni." (Kornai 1996:162, kiemelés tőlem: F.J.) „A jóléti állam a 20. század legnagyobb társadalmi vívmánya.” mondja Berend T. is (2003:1278).

Az új kihívásokhoz új módszerek, új eszközök, új utak kellenek. Nem a profitmaximalizálás az emberi társadalom fejlődésének alfája és omegája, mint ahogy a „társadalmi-hatékonyság”, az „életképesség” meghatározása is csak egyik alternatívája lehet az előrelátó, új megoldások keresésének. ${ }^{33}$

Mit hoz a jövő? „A jövő a múltban van” - mondják a csillagászok. Magam is így vélem, kiegészítve azzal, hogy a jelen és a jövő megoldása nem a múlt tagadása, hanem annak hasznosítása révén remélhető. Szakítani kellene tehát azzal a hagyománnyal, rossz szokással, amit Hegel keserüen így fogalmazott meg: „... a történelem tanulsága, hogy a népek és kormányok soha, semmit sem tanultak belöle...”, és hallgatni kellene Ciceróra: „A történelem az élet tanitómestere." 


\section{Hivatkozások}

Akerlof, G.A. (1970): The Market for „Lemons”: Qualitative Uncertainty and the Market Mechanism. Quarterly Journal of Econonics, vol. 84. no. 3: 488-500.

Arrow, Kenneth F. (1963): Uncertainty and the Welfare Economics of Medical Care. American Economic Review, vol. 53. no. 6: 941-973.

Arrow, Kenneth F. (1973): Higher education as a filter. Journal of Public Economics, 2: 193-216.

Bara Zoltán - Csaba László - Gedeon Péter (2000): Összehasonlitó gazdaságtan és közgazdaságtan. In: Bara - Szabó szerk.: Gazdasági rendszerek, országok, intézmények. Budapest, Aula Kiadó, 3-51. old.

Bara Zoltán - Szabó Katalin, szerkesztők (2000): Gazdasági rendszerek, országok, intézmények. Budapest, Aula Kiadó, 609. old.

Barr, Nicholas (1999): Állami beavatkozás. In: Csaba Iván - Tóth István György, szerk.: A jóléti állam politikai gazdaságtana. Budapest, Osiris Kiadó - Láthatatlan Kollégium, 112-145. old.

Bauer Tamás (1982): A második gazdasági reform és a tulajdonviszonyok. Mozgó Világ, 8. évf. 1: 17-42.

Berend T. Iván (2003): A jóléti állam: válság és kiutak. Magyar Tudomány, 10: 1273-1278. Brus, Wlodzimierz (1966): A szocialista gazdaság müködésének általános problémái. Budapest, Közgazdasági és Jogi Könyvkiadó, 245.old.

Buchanan, James M. (1992): Piac, állam, alkotmányosság. Budapest, Közgazdasági és Jogi Könyvkiadó, 296. old.

Csaba Iván - Tóth István György, szerk.: (1999): A jóléti állam politikai gazdaságtana. Budapest, Osiris Kiadó - Láthatalan Kollégium, 378. old.

Csaba Iván - Tóth István György (1999): A jóléti állam politikai gazdaságtana. In: Csaba I. - Tóth I. Gy. szerk.: A jóléti állam politikai gazdaságtana. 7-37. old.

Csaba Iván (1991): A jóléti állam privatizációja Nagy-Britanniában. Esély, 3: 81-98.

Csaba László (2000/a): A szovjet modell. In: Bara - Szabó szerk.: Gazdasági rendszerek, országok, intézmények. Budapest, Aula Kiadó, 245-267. old.

Csaba László (2000/b). Az átalakulás sokszólamúsága. Európai Szemle, XI. évf. 2: 61-83. Csaba László (2002): Az átalakulás fejlődéselmélete. Közgazdasági Szemle, XLIX. évf. 4: 273-291.

Fekete Judit (1990): A „puccs” mint irányítási módszer. Közgazdasági Szemle, XXXVII. évf. 5: 559-572.

Fekete Judit (2002/a): Politika, kríziskezelés, vállalkozás. Budapest, Kairosz Kiadó, 283. old.

Fekete Judit (2002/b): Alapszemlélet a jövőhöz. In: Bulla Miklós - Tamás Pál szerk.: Mühelytanulmányok Magyarország környezeti jövőképéröl. Budapest, az Országos Környezetvédelmi Tanács és a Magyar Tudományos Akadémia Szociológiai Kutatóintézet kiadása, 7-33. old.

Gábor R. István - Galasi Péter (1978): A „másodlagos gazdaság”, a szocialimusbeli magánszféra néhány gazdaságszociológiai kérdése. Szociológia, 3: 329-344.

Gábor R. István (1979): A „második” (másodlagos) gazdaság. Valóság, 22 évf. 1: 22-36. Gazdasági rendszerek, országok, intézmények. Budapest, Aula Kiadó, 209-242. old. 
Gota Esping - Andersen (1999): A jóléti államok az évszázad végén: A munkaerőpiaci, a családszerkezeti és a demográfiai változások hatása. In: Csaba Iván - Tóth István György szerk.: A jóléti állam politikai gazdaságtana. Budapest, Osiris Kiadó - Láthatatlan Kollégium, 89-111. old.

Hámori Balázs (2000): Reformszocialista kísérletek. Piaci szocializmus, avagy a reformok korlátai. In: Bara - Szabó, szerk.: Gazdasági rendszerek, országok, intézmények. Budapest, Aula Kiadó, 269-325. old.

Hayek, Friedrich (1995): Piac és szabadság. Budapest, Közgazdasági és Jogi Könyvkiadó, 513. old.

Kornai János (1993/a.) : Útkeresés. Budapest, Századvég Kiadó, 254. old.

Kornai János (1993/b): A szocialista rendszer. Budapest, Heti Világgazdaság Kiadó RT. 670. old.

Kornai János (1996): Vergődés és remény. Budapest, Közgazdasági és Jogi Könyvkiadó, 336. old.

Kornai János (1998): Az egészségügy reformjáról. Budapest, Közgazdasági és Jogi Könyvkiadó, 184. old.

Kornai János (1999): A rendszerparadigma. Közgazdasági Szemle, XLVI. évf. 7-8: 585599.

Köves András - Szamuely László (1997): Élbolyban - haladunk? Gondolatok idöszerü gazdaságpolitikai kérdésekről. Gazdaság, XXX. évf. (Új folyam VI.) 2: 40-48.

Ladányi János - Szelényi Iván (1997): Vázlat az „esélyteremtő állam” elméletéhez. A jóléti államon és a neokonzervativizmuson túl. Gazdaság, XXX. évf. (Új folyam VI.) 1: 68-79. Laki Mihály (1980): A háttéripar fejlesztése. Gazdaság, XIV. évf. 3: 61-73. old.

Laki Mihály (1983): Vállalatok megszünése és összevonása. Budapest, Közgazdasági és Jogi Könyvkiadó, 215. old.

Le Grand, Julien (1999): A kormányzati kudarcok elmélete. In: Csaba Iván - Tóth István György, szerk.: A jóléti állam politikai gazdaságtana. Budapest, Osiris Kiadó - Láthatatlan Kollégium. 146-164 old.

Lieberman (1956): Hozjajsztvennij raszcsot i materialnaja zaintereszovannoszt rabotnikov promislennoszti. Voproszi Ekonomiki, 6.

Lindbeck, Assar (1998/a): A svéd kísérlet - I. rész. Külgazdaság, XLII. évf. 7-8: 57-89.

Lindbeck, Assar (1998/b): A svéd kísérlet II. rész. Külgazdaság, XLII. évf. 9: 56-74.

Liska Tibor (1988): Ökonosztát. Budapest, Közgazdasági és Jogi Könyvkiadó, 320. old.

Losonczi Ágnes (1986): A kiszolgáltatottság anatómiája az egészségügyben. Budapest, Magvető Kiadó, 259. old.

Losonczi Ágnes (1989): Ártó-védő társadalom. Budapest, Közgazdasági és Jogi Könyvkiadó, 351. old.

Nagy András (1993): Átmenet? Honnan hová? Valóság, XXXVI: évf. 9: 1-18.

Nagy András (1998): A jóléti rendszer Franciaországban. Közgazdasági Szemle, XLV. évf. 5: 456-478.

Nagy András (2001): Az intézmények átalakulása és a fejlett gazdaságok utolérése. Közgazdasági Szemle, XLVIII. évf. 11: 920-949.

Offe, Claus (1984): Contradictions of the Welfare State. London, Hutchinson Education. Samuelson, Paul (1969): Pure theory of public expenditure and taxation. In: J. Margolis - H. Guitton, eds.:Public Economics. London, Macmillan Press Ltd. 
Szabó Katalin (2000): A jóléti államtól az esélyteremtő államig. In: Bara - Szabó szerk.: Gazdasági rendszerek, országok, intézmények. Budapest, Aula Kiadó, 209-242. old.

Szabó Katalin - Kocsis Éva (2002): Digitális paradicsom vagy falanszter? Budapest, Aula Kiadó, 233. old.

Szamuely László - Csaba László (1998): Rendszerváltozás a közgazdaságtanban - közgazdaságtan a rendszerváltozásban. Budapest, Közgazdasági Szemle Alapítvány, 185. old.

Tellér Gyula (1984): Ómechanizmus, újmechanizmus, ipari szövetkezetek. Budapest, Szövetkezeti Kutatóintézet, kézirat.

Tóth István György (1994): A jóléti rendszer az átmenet időszakában. Közgazdasági szemle XLI. évf. 4: 313-340.

Tölgyessy Péter (1984): A kisiparosság érdekstruktúrája és szervezete. Budapest, Társadalomtudományi Intézet, kézirat, 186. old. 